\title{
Canada's First Bookseller's Catalogue
}

\author{
Sandra Alston
}

One of the most satisfying aspects of the research undertaken on the supplement to Marie Tremaine's classic $A$ Bibliography of Canadian Imprints, $1752-1800^{\mathrm{I}}$ has been the discovery of previously unknown or unlocated items. Among the most interesting discoveries has been a copy of item number I 88 , described in the bibliography as follows:

I I 88. Neilson, John, I776-I 848 .

[Catalogue of Books for Sale, 3 Mountain St.Quebec, I 80o.]

Leaflet of 2 or 4 pages. Printed at Quebec, by John Neilson, I800.

Neilson recorded this Catalogue in his advertisement: 'Imported from London in the Brickwood, and will be ready for sale tomorrow at the Printing Office, 3 Mountain Street, for Cash only - A small assortment of new and valuable French and English books, of which Catalogues may be had at the Office.'-Quebec gazette, Nov. 20, I 800 .

This seems to be the publication of which a copy was listed by Dora Hood, Toronto, in her Catalogue no. 4, Autumn, I930 (which included works from the collection of Col. J. Hubert Neilson, a grandson of the printer), item no. 316. Mrs Hood recalls the item as a leaflet of 2 or 4 pages, sold for 75 cents.

Copy known but not located: J. Hubert Neilson copy supra.

This citation ${ }^{2}$ was the only clue to the existence of this early Neilson book catalogue, apparently the very first such bookseller's catalogue printed in

Sandra Alston holds a joint appointment in the Thomas Fisher Rare Book Library and the Selection Department in the University of Toronto Libraries. 
Canada. Marie Tremaine lists thirteen earlier catalogues, ${ }^{3}$ all of books and other items for sale at auction. Only one of these, number 787 , the Catalogue of the libraries of the late Honorable Adam Mabane, and Alexander Gray ..., printed by Samuel Neilson in 1792, has been located, at the Séminaire du Québec, in Québec City.

A search for this item in the Eighteenth-Century Short-Title Catalogue (ESTC) database on the Research Libraries Information Network produced one record. Cited as item \# wor6672, the catalogue was listed as being at the Houghton Library, Harvard University, accession number 69-683. ${ }^{4}$ Accession records showed that the Houghton had purchased the title from Goodspeed's Book Shop in March of 1970 for seventy-five dollars. ${ }^{5}$

Beyond the joy of discovering a hitherto unlocated Tremaine imprint was the realization that this particular copy, obviously the one described as item II 88 , is extensively annotated in Neilson's own hand; additions have been made to the text, items sold have been crossed out, and often the person to whom the book was sold has been inserted.

John Neilson (I776-I848) joined his brother Samuel's printing firm in I79I at the age of fifteen, and inherited the business two years later. Through shrewd financial management and business acumen he built it into the most prominent and influential printing shop, newspaper office, and bookshop, not only in the city of Quebec, but throughout British North America. As well as selling his own printed books and pamphlets he began to import titles from England and the United States, advertising them in the Quebec Gazette, and acting as both a wholesaler and a retailer of books. He also tried to import books from France, but war between Great Britain and France during this period complicated those dealings. Married to a niece of the Roman Catholic bishop of Quebec, and fluently bilingual, Neilson had business and familial connections to both French and English society in the colony.

Prior to 1800 Neilson had advertised books for sale in the columns of the Quebec Gazette, but this catalogue - a small octavo of sixteen pages is the first to appear as a separate text. Neilson has inscribed on the front cover: 'Any of the Books in Catalogue not sold out \& not in Shop are upstairs W. Cowan if they should be wanted can get the Key \& bring them down. J.N.'

John Hare and Jean-Pierre Wallot, in their article on the Neilson bookshop, ${ }^{6}$ studied the books sold by the firm based on five catalogues published in I802, I803, I8II, I8I7, and I8I8, as well as on the Neilson papers held by the National Archives of Canada. Some brief comparisons to those later catalogues can be made.

The I 800 catalogue, like Neilson's later catalogues, has been divided into books arranged by format - folio, quarto, octavo, and duodecimo - and 
by subject - classics, dictionaries, French and English grammar and school books, political pamphlets, plays, etc. There is a very small degree of duplication of the categories. A total of 265 titles are listed; 2 I2 $(80 \%)$ in English, 4I (I 5.5\%) in French, 3 (I.I\%) in Italian, and $9(3.4 \%)$ in Latin. Neilson's next printed catalogue, not published separately but as part of the supplement to the Quebec Gazette, no. I93 I (I5 April I802), contains 254 titles, I $82(71.7 \%)$ in English, $58(22.8 \%)$ in French, and I4 (5.5\%) others. It is interesting to speculate on the reasons for the increase in the number of French titles; it may reflect customer demand, but equally likely it reflects availability.

Hare and Wallot examined the titles in other Neilson catalogues using the chart developed by François Furet, ${ }^{7}$ which lists twenty-six categories of subjects under five broad headings - religion and theology, law and jurisprudence, history, arts and science, and belles-lettres. Following that scheme one finds a subject breakdown as follows: religion and theology, Io titles $(3.8 \%)$; law and jurisprudence, ro titles $(3.8 \%)$; history, 8 I titles $(30.6 \%)$; arts and science, 6I titles $(23.0 \%)$; belles-lettres, 9I titles $(34.3 \%)$; unknown, I 2 titles $(4.5 \%)$.

In examining the categories it is easy to ascertain from manuscript annotations the more popular works - history, biography, voyages and travels, medical and legal treatises, and literature. It is interesting that several categories seem to have elicited no interest at all, among them classics and dictionaries.

Products of the local press cannot be assigned to the categories listed above, but work to date on eighteenth-century Canadian printing shows the following breakdown of material actually printed in Canada: almanacs (I $5.5 \%$ ); belles-lettres, $(0.9 \%$ ); government (i.e. laws, debates, proclamations of government officials) $(45.8 \%)$; religion and theology (I2.7\%); school texts $(3.2 \%)$; other (i.e. advertisements, announcements, etc.) $(21.9 \%)$.

Neilson's shop was patronized by the elite of both English and French society in the city of Quebec. Lawyers and notaries Olivier Perrault and Pierre-Louis Deschenaux purchased legal treatises and the collected works of Montesquieu. Jean Thomas Tascherau, a lawyer, showed a wide range of interest with his purchases of Charles Hutton's Mathematical and Philosophical Dictionary, the Lex Parliamentaria, Newton's Natural Philosophy, and Thomas Pownall's great treatise on the administration of the colonies. Bishop Jacob Mountain, Anglican bishop of the diocese of Quebec, bought Wilkins's Universal and Biographical Dictionary. John Black, Sir John Caldwell, John Young, and Thomas Grant, all closely allied in business, bought texts on subjects as diverse as cookery, the river police, poetry, philosophy, and medicine. 
The breadth and depth of subjects listed in the catalogue demonstrate to some extent the calibre of the elite in the colony of Quebec. It is hoped that the reproduction of this unique catalogue, with its extensive manuscript annotations will provide more evidence to enable scholars to study the social and intellectual history of Canada. ${ }^{8}$

NOTES

I Marie Tremaine, A Bibliography of Canadian Imprints, I75 I-I800 (Toronto: University of Toronto Press, 1952).

2 Unfortunately to be found in the index to the book only under the heading 'Book Catalogue.'

3 Numbers 336, 363, 384, 443, 509, 526, 597, 758, 787, 97 I, I090, I I 22 , and I I 43.

4 Previous visits to the Houghton Library had failed to turn up the item, as it was accessible only through the union catalogue in the Widener Library, and not through Houghton Library's own catalogue.

5 Goodspeed's has informed the author that they have no record of the source of the pamphlet.

6 John Hare and Jean-Pierre Wallot, 'Le livre au Québec et la librairie Neilson au tournant du XIx ${ }^{\mathrm{e}}$ siècle,' in Livre et lecture au Québec (I 800-I850) (Québec: Institut québécois de recherche sur la culture, I988): 93-I I 2 ,

7 François Furet, 'La "librairie" du royaume de France au I8e siècle,' in Livre et société dans la France du XVIIIe siècle (Paris: Mouton, I965): I4-I6.

8 The catalogue is reproduced by the permission of the Houghton Library, Harvard University. 
I I Alston: Canada's First Bookseller's Catalogue

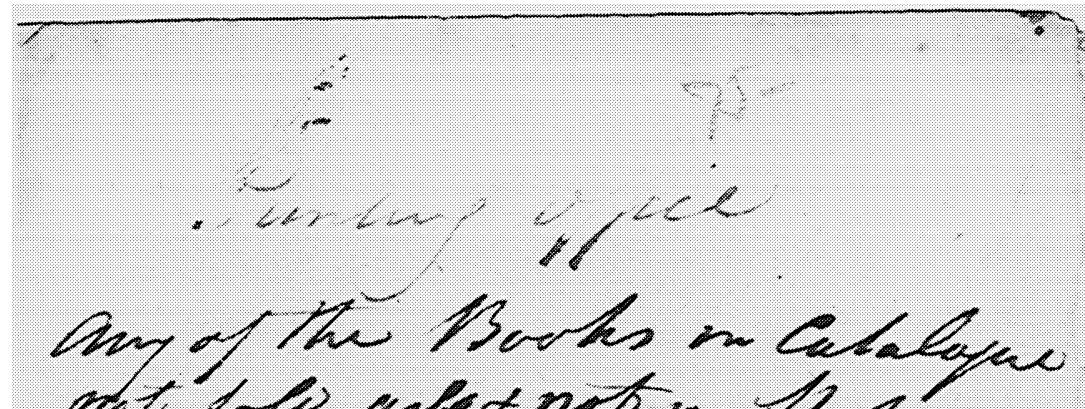
not tole anted not ah tho are

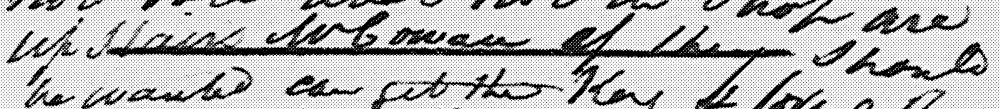

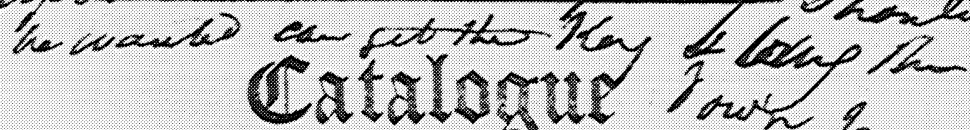
Catalogue own $\%$

Of English French and Latin Books, for sale at the PRINTING OFFICE $n^{2} 3$ Mountain street, Quebec.

1800.

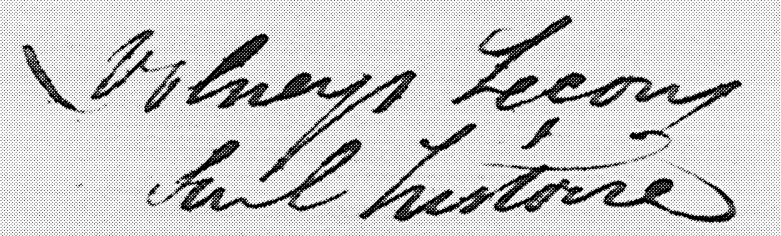

$\checkmark$ Jane Zowamina

$\checkmark$ Fencers. Elecheres Leary Weeing L

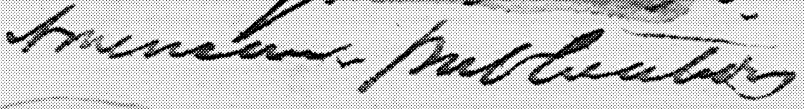




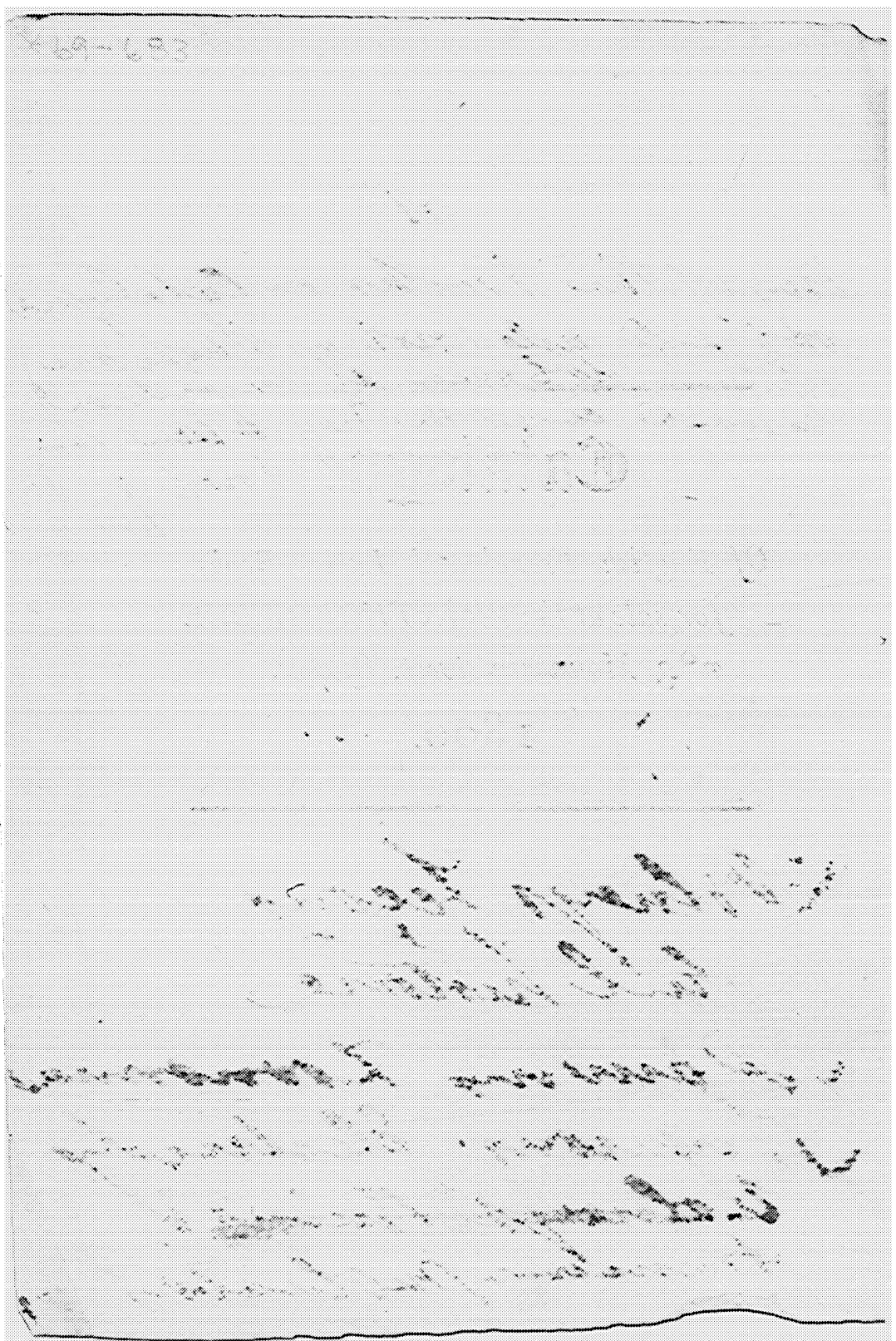




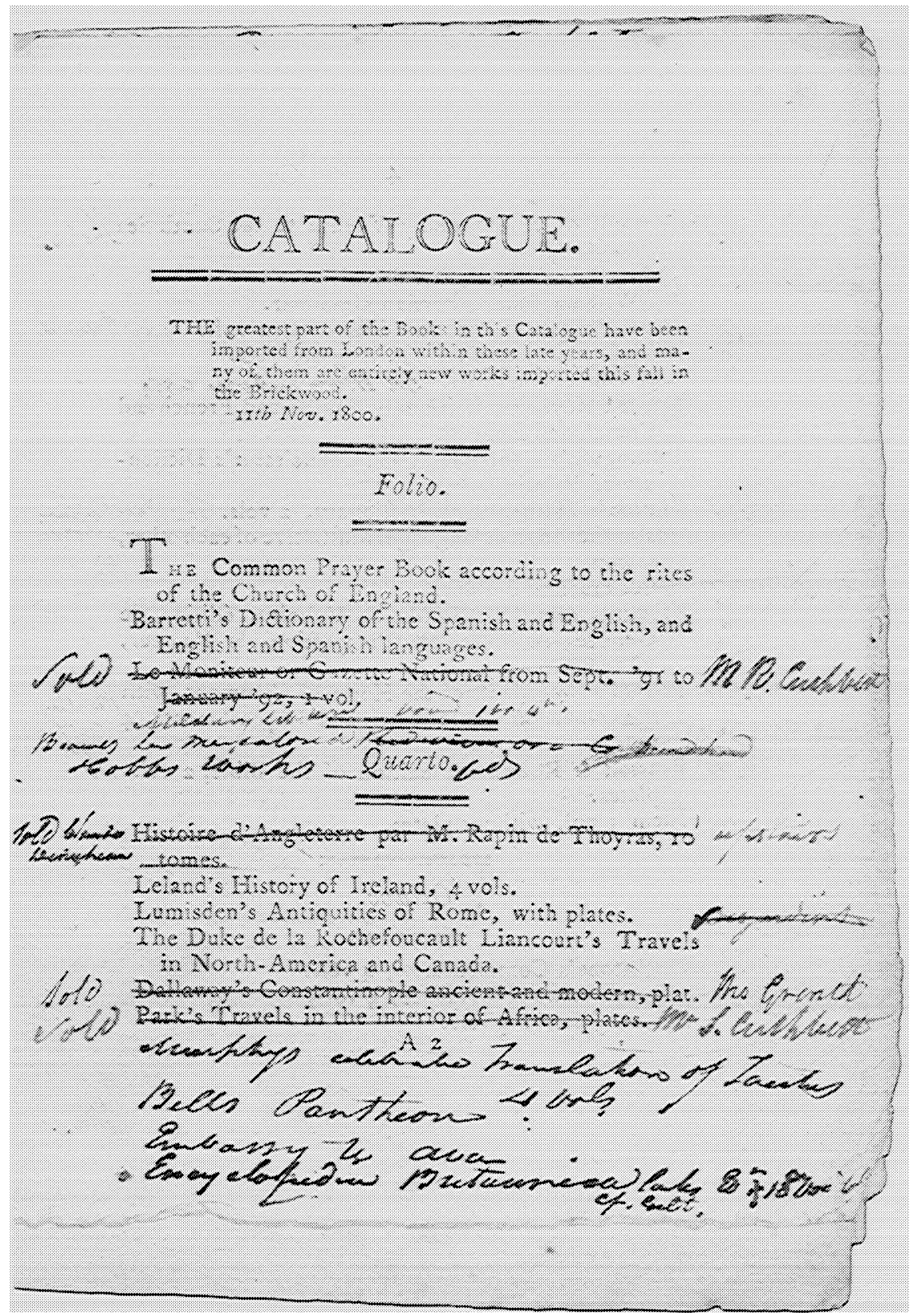




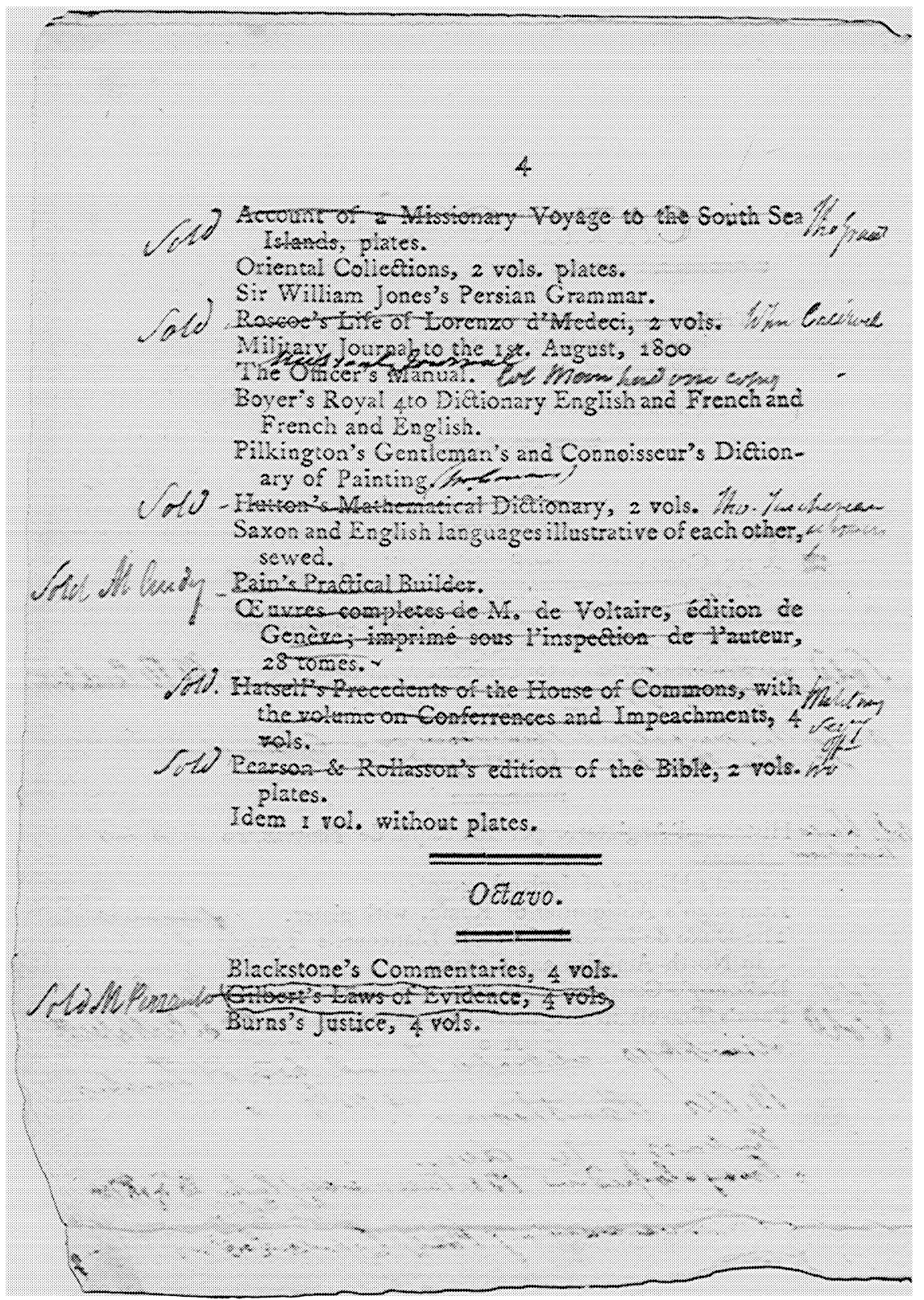




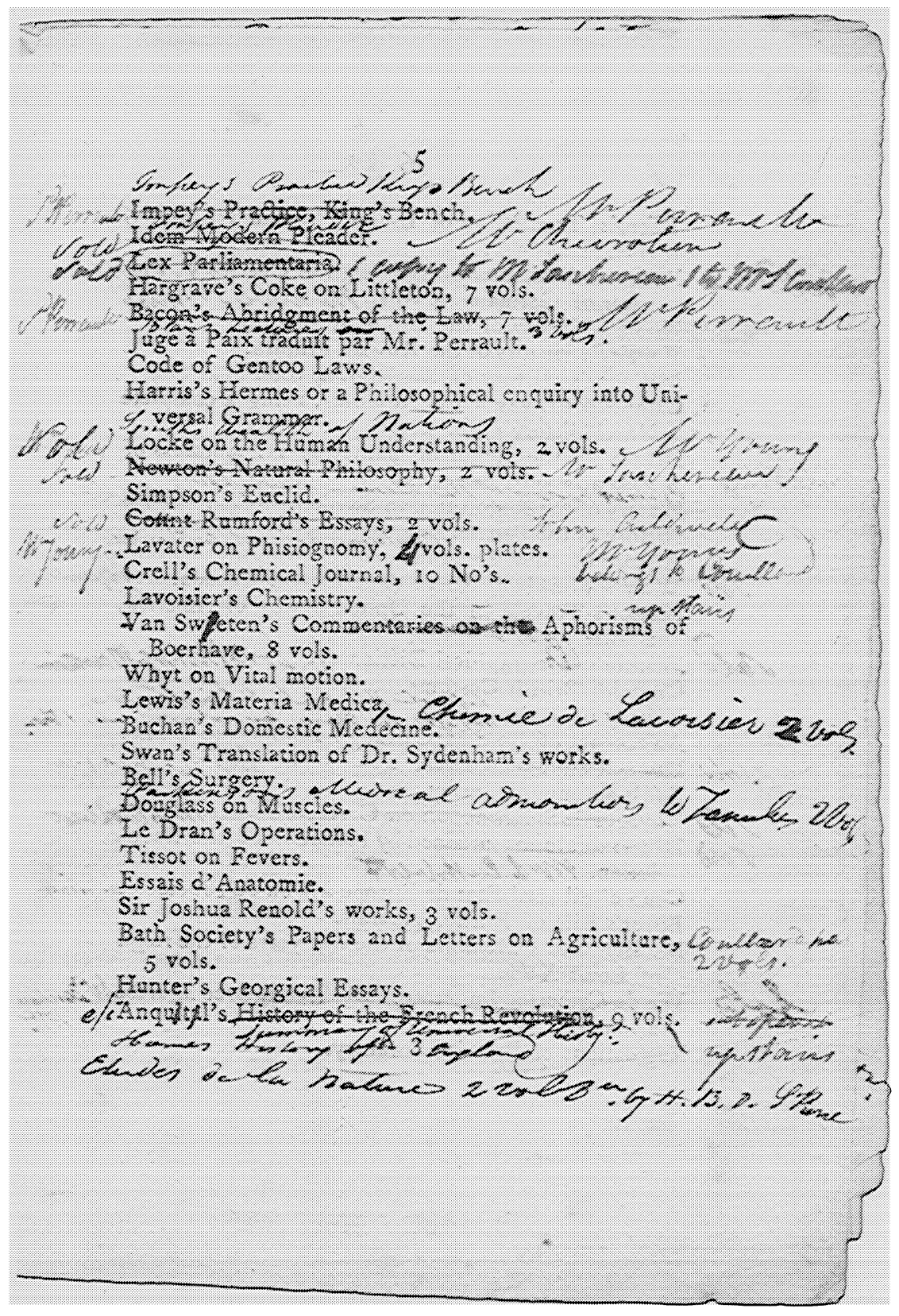




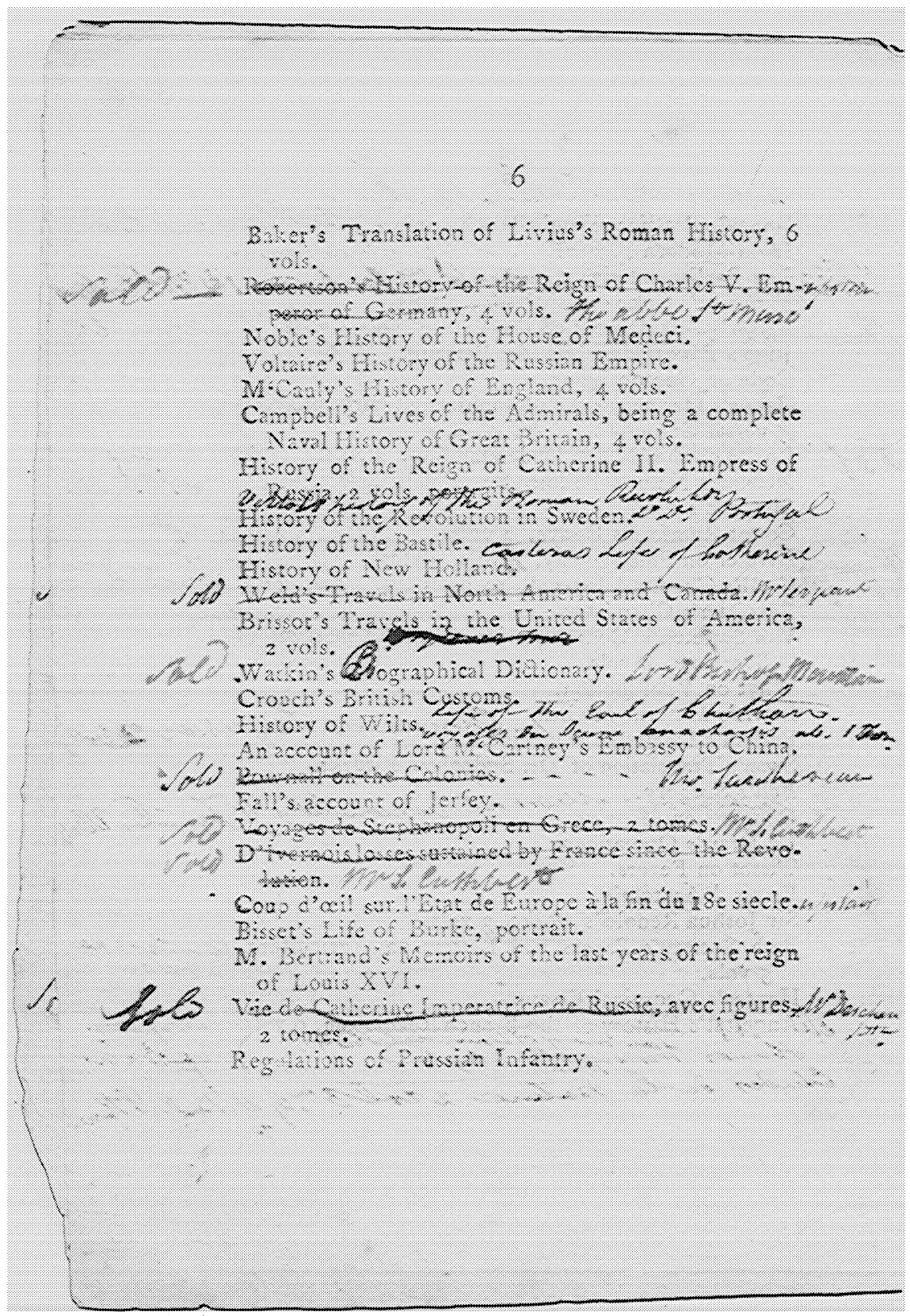




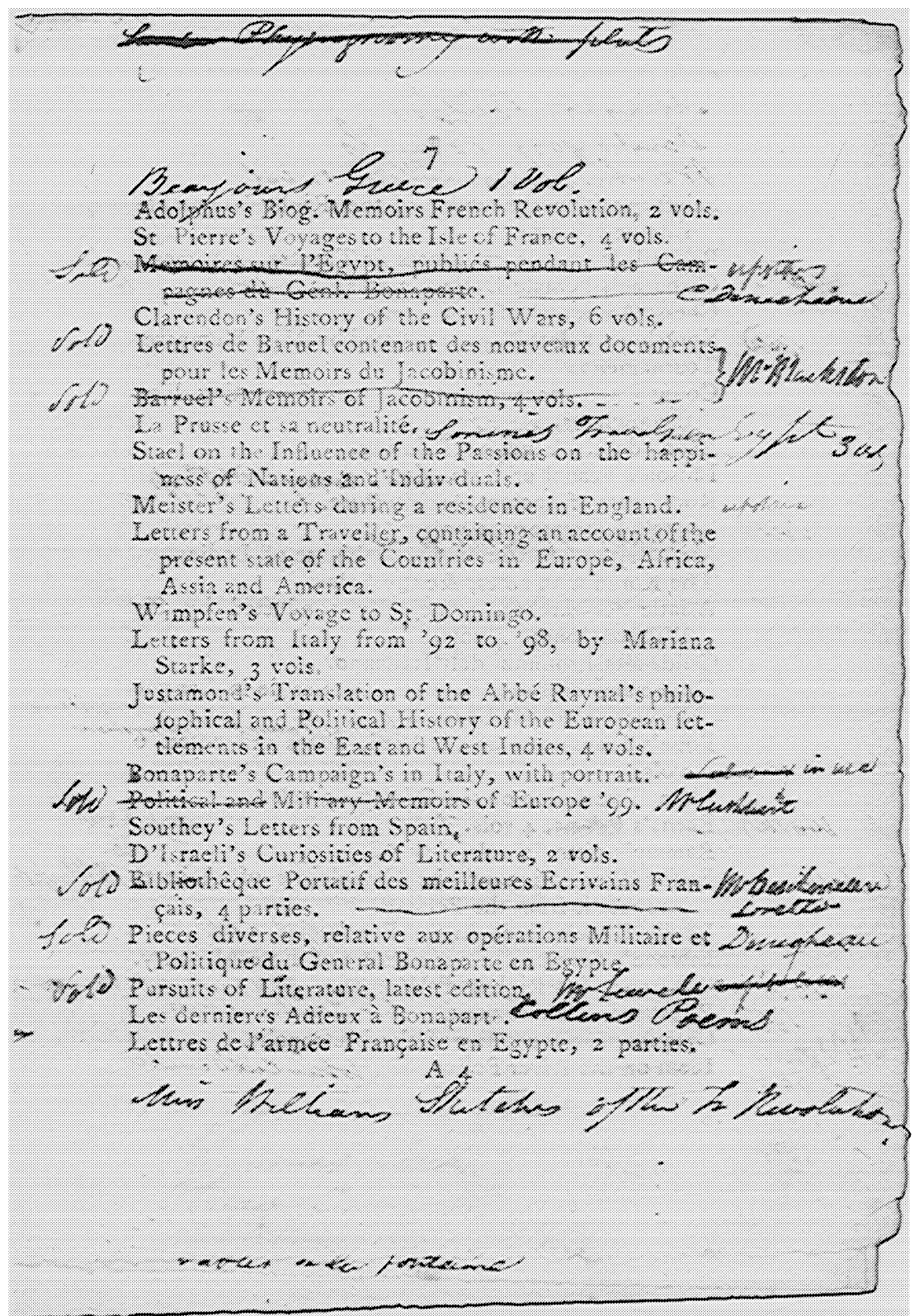




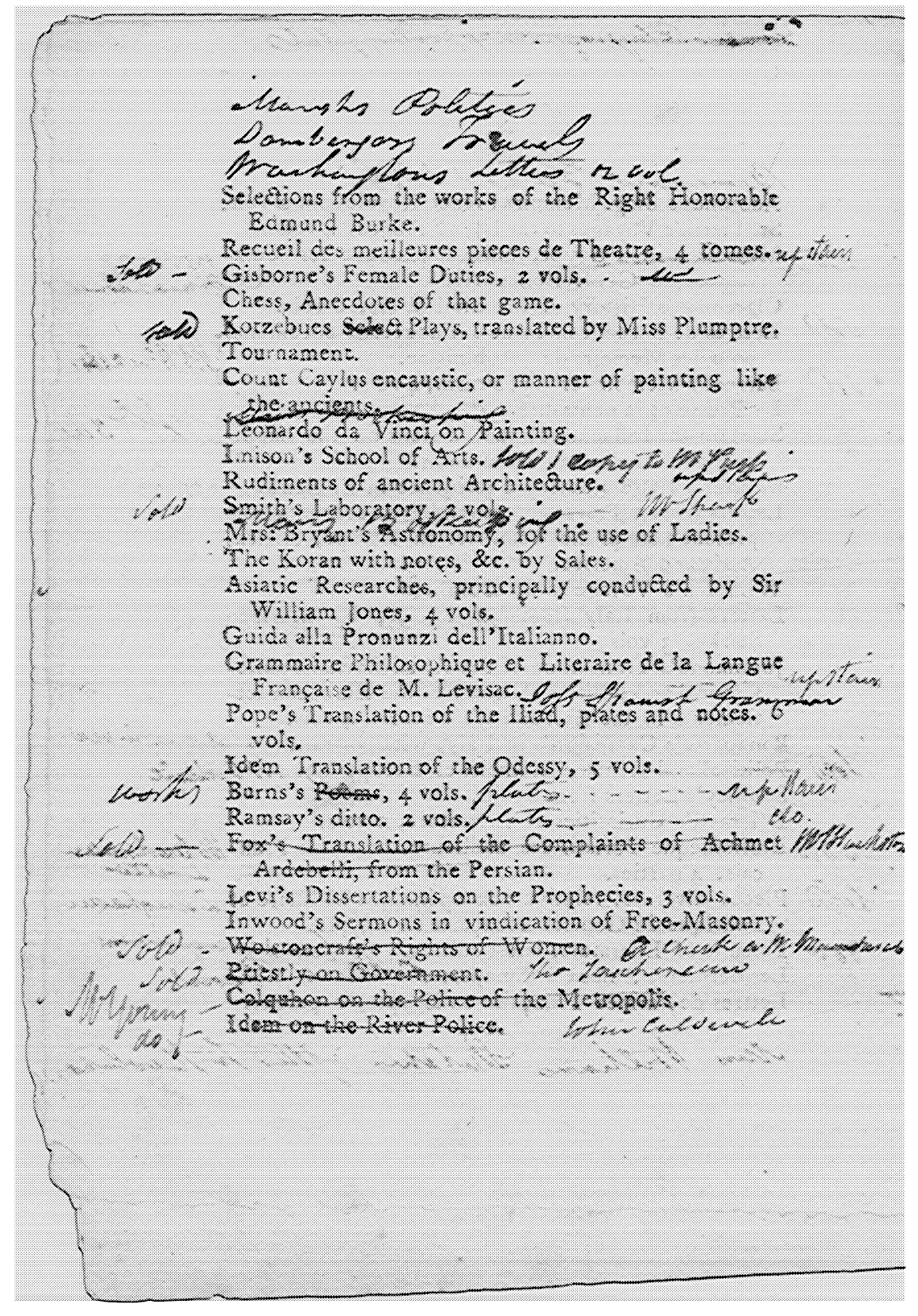


I9 Alston: Canada's First Bookseller's Catalogue

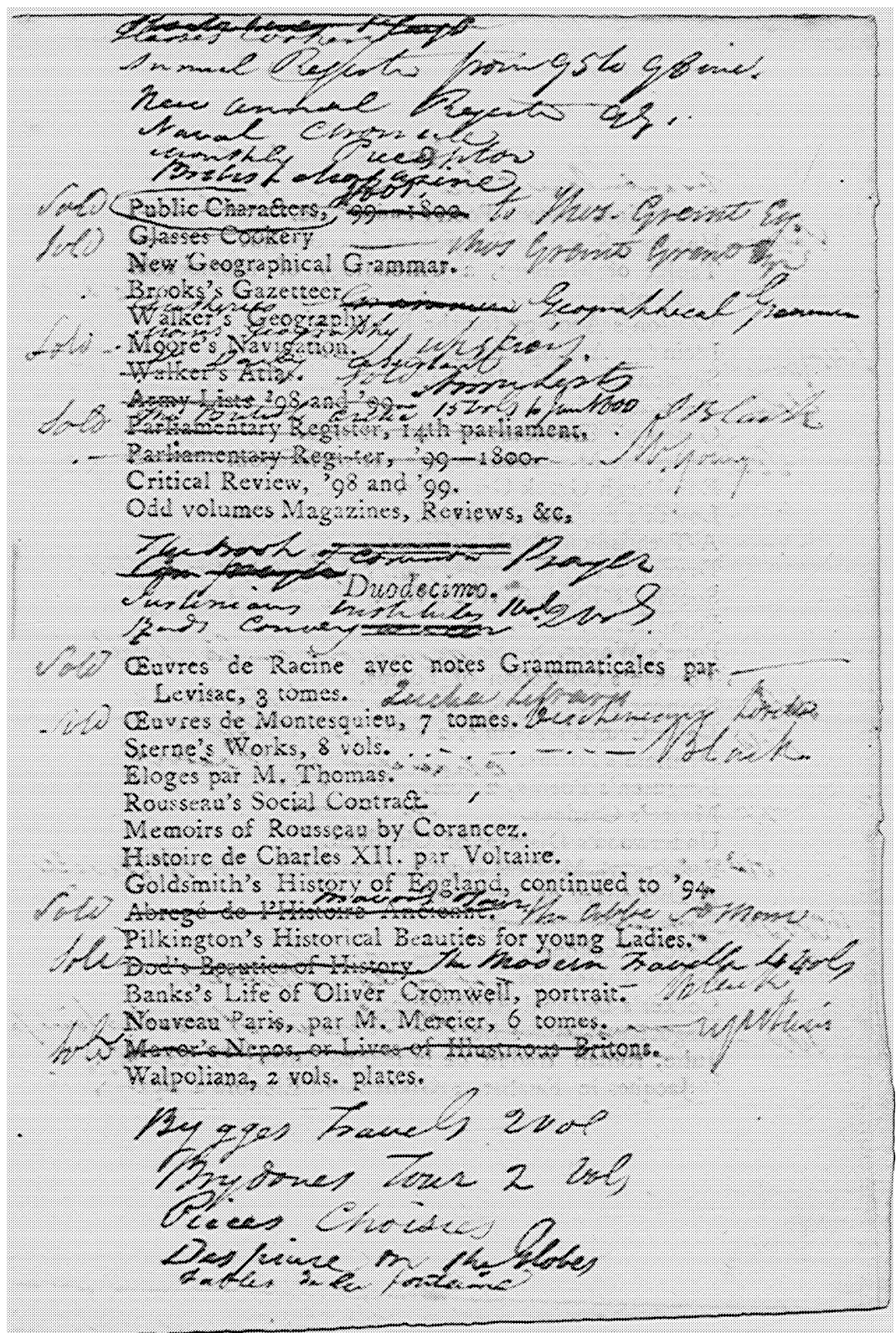




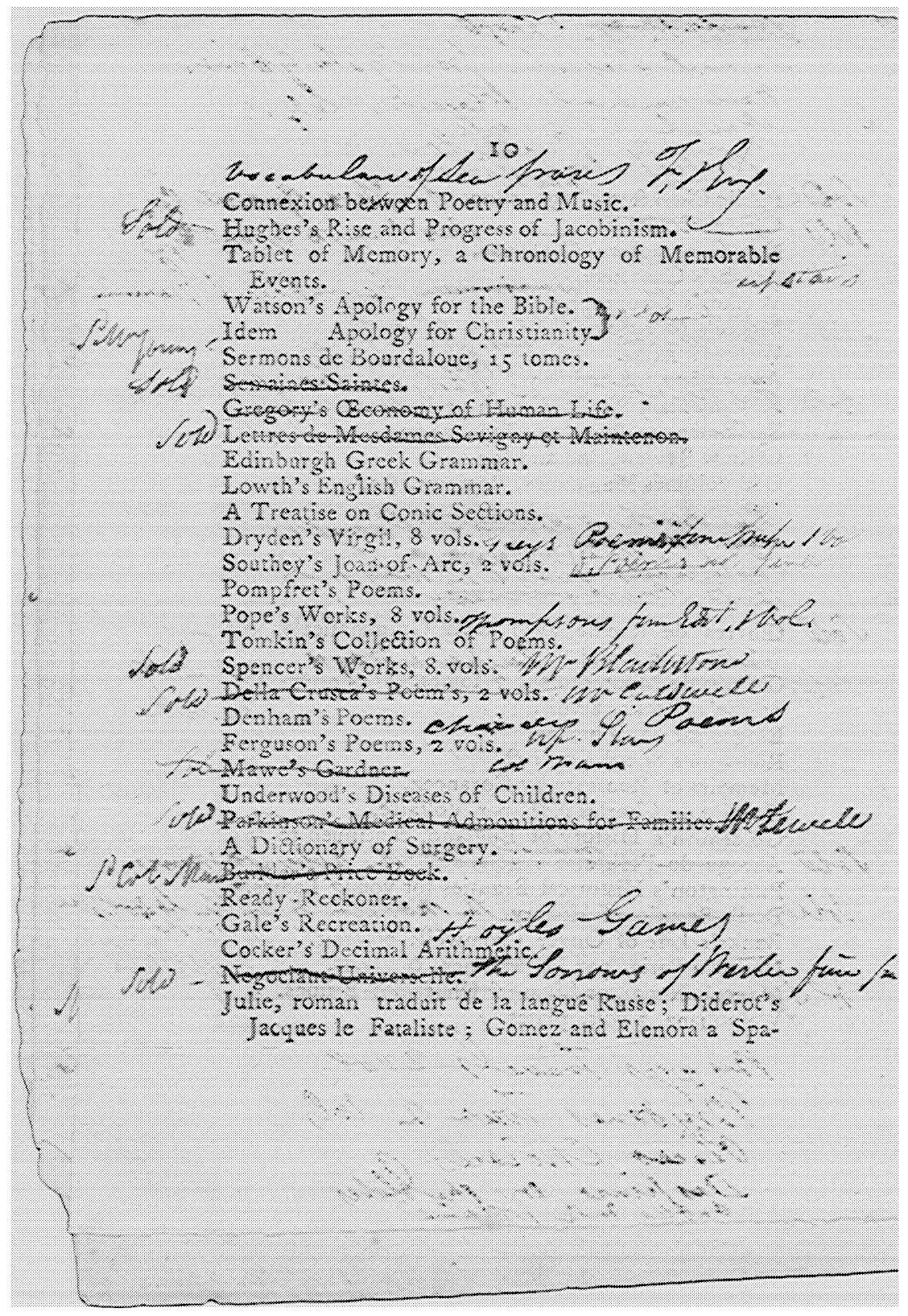




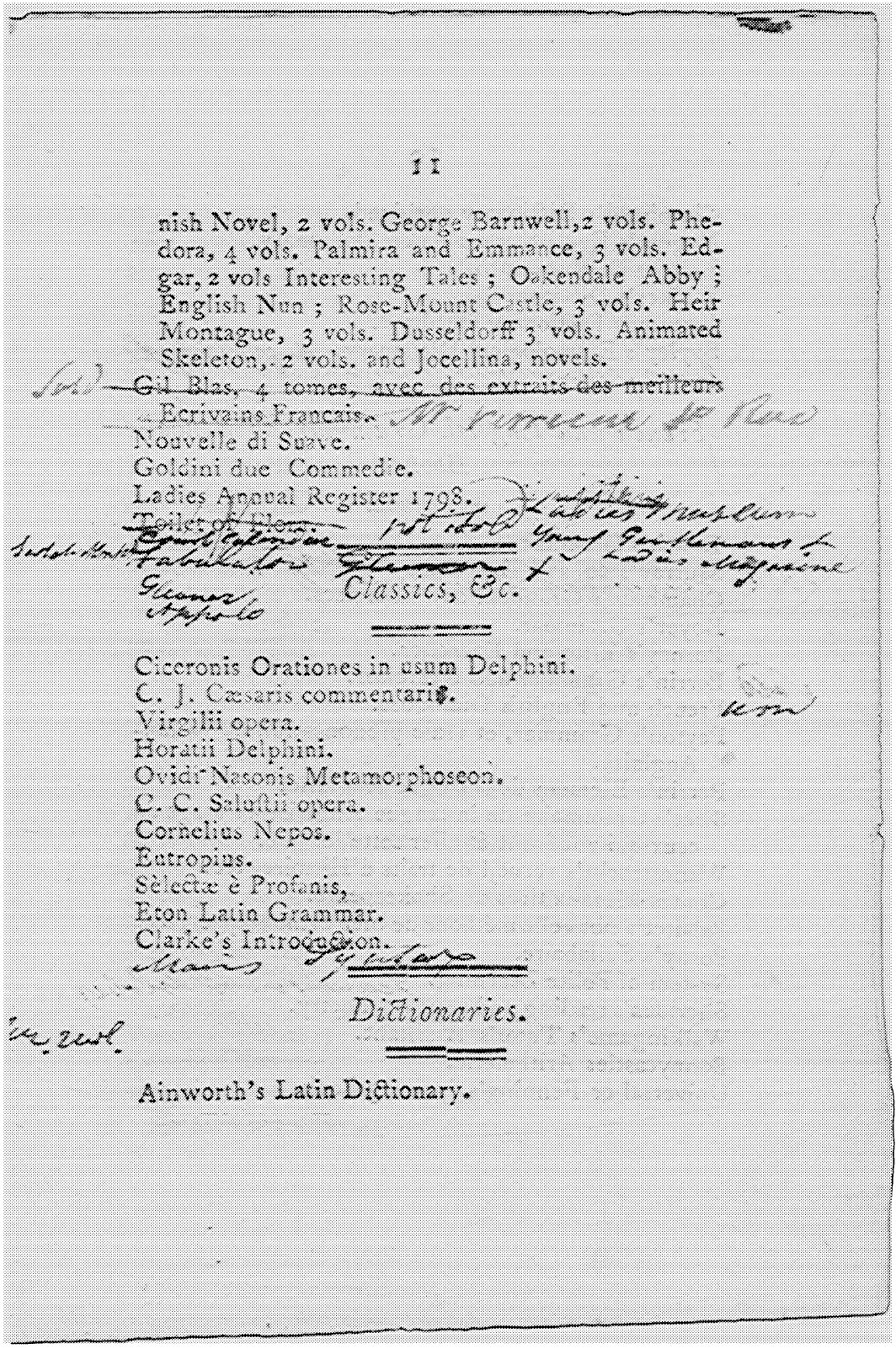




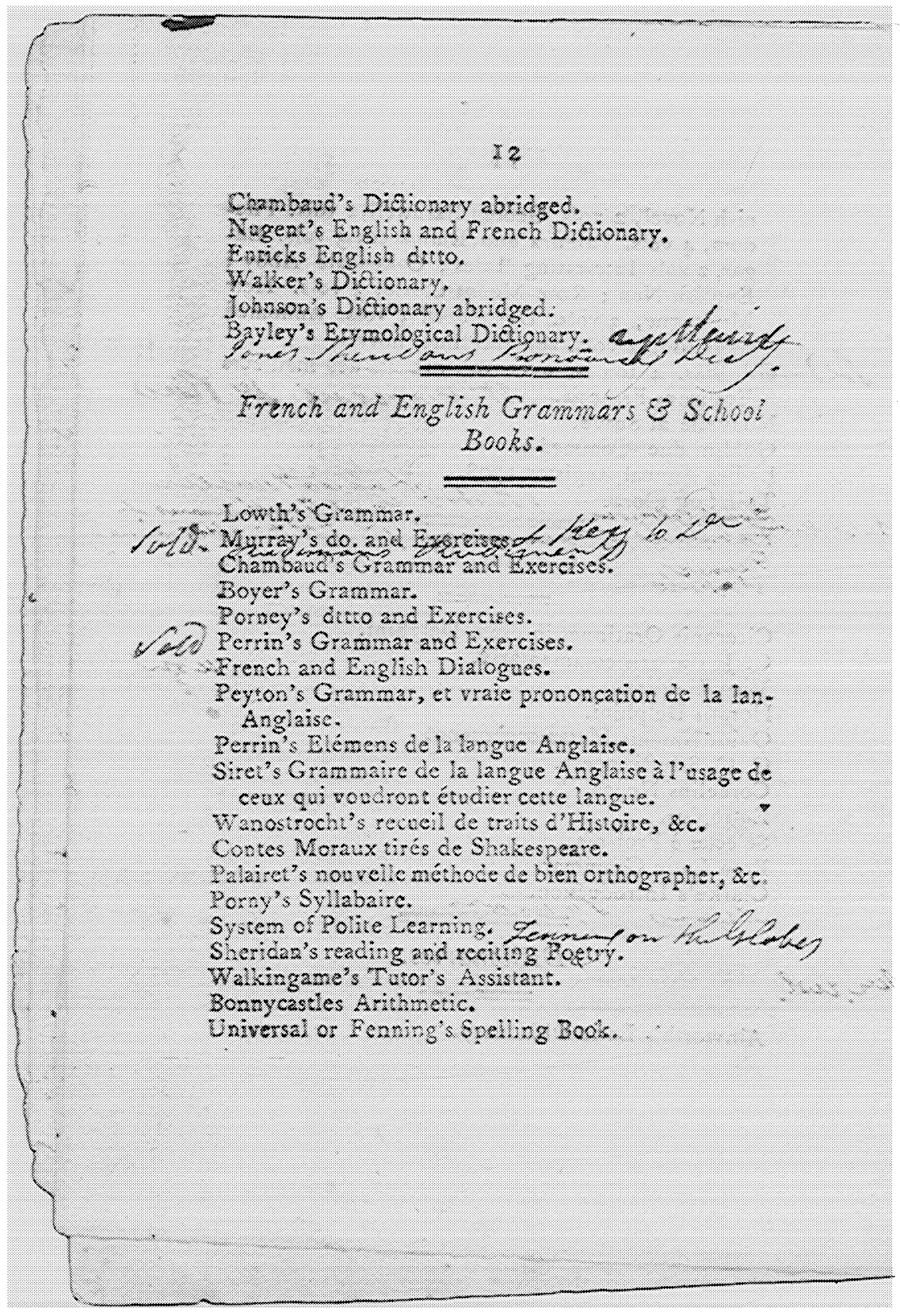




\section{3}

Dyche's Spelling.

Dilworth's, or New Guide.

Horn Books and variety of Chlldren's Books.

Catechisms Clumrch of England.

Watt's Hyms.

New Testaments, 8ro. Z:bles, \&re.

\section{Political Pamphlets, Plays, Ec.}

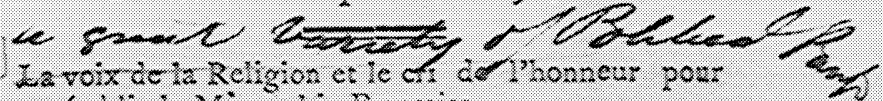
zétablir la Mónarchie Française.

Relation de la deportation de Barthelemy, Pichegru, /mrffuallax \&c. 2 Cayenne.

Dive-inzigitsh.

Reponse de Carno: au rapgort de Ballieul.

Fothergill on Spirits.

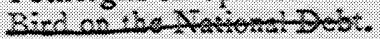

Ramel's Sarrativesiz-Exgitsh.

Mallet du Pan's Mercury to July $2799 *$

Kant's Perpetual Peace.

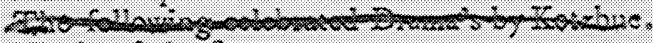

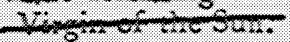

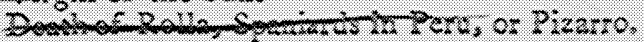

Namural Son.

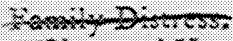

Widow and Horse.

Peyrouse.

Force of Calumny.

Count of Burgundy.

Castle of Montral! 
24 Papers of the Bibliographical Society of Canada $30 /$ I

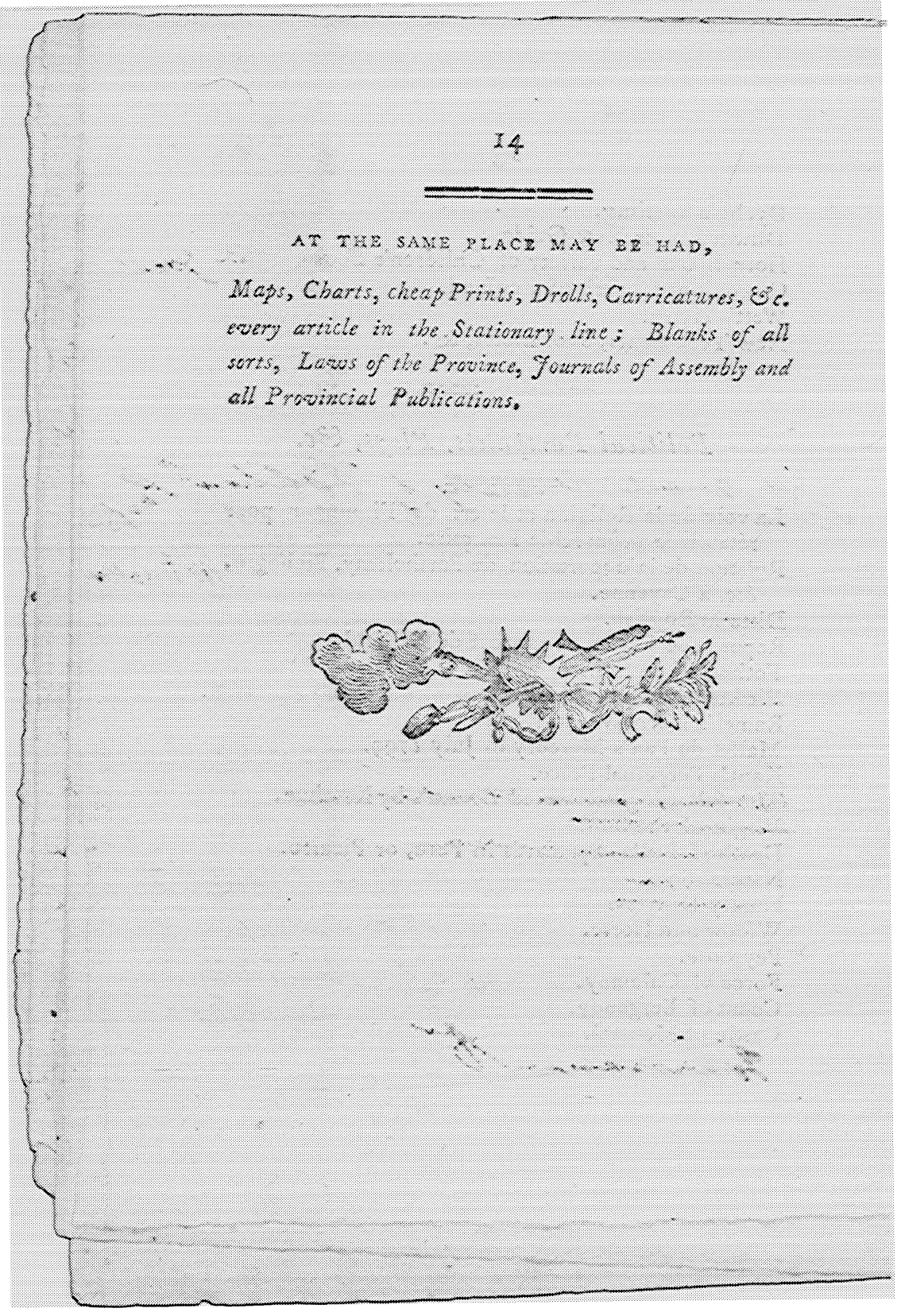


25 Alston: Canada's First Bookseller's Catalogue 
26 Papers of the Bibliographical Society of Canada $30 / \mathrm{I}$

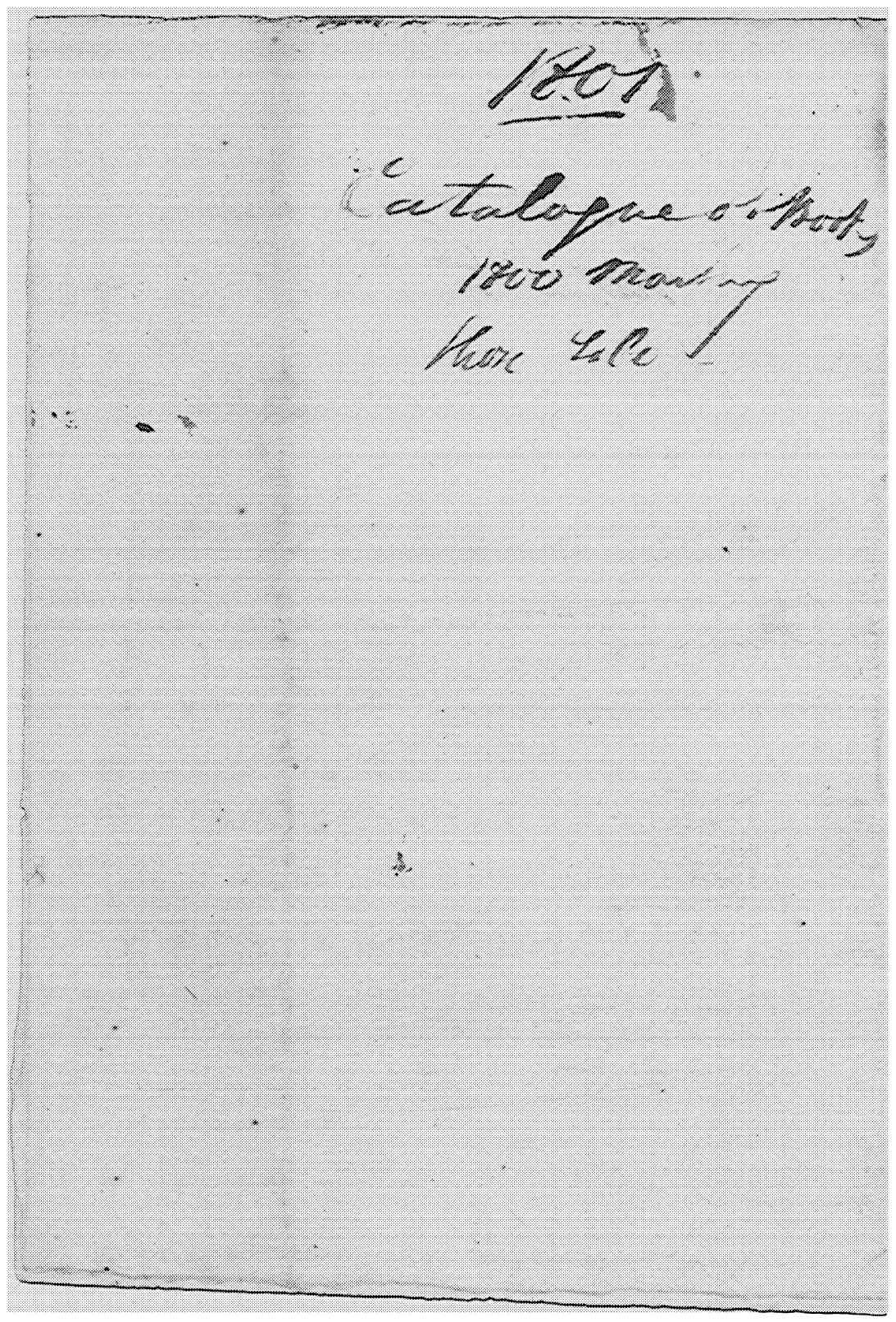

